\title{
Rapid serum agglutination and agar gel immunodiffusion tests associated to clinical signs in rams experimentally infected with Brucella ovis
}

\author{
Teste de soro aglutinação rápida e do teste de imunodifusão em gel de ágar associados aos sinais \\ clínicos em carneiros infectados experimentalmente com Brucella ovis
}

\author{
Cristiane Nakada Nozaki ${ }^{I}$ Nair Silva Cavalcanti de Lira ${ }^{I}$ Otávio Augusto Filho \\ Hymerson Costa Azevedo ${ }^{\text {II }}$ Leandro Rodello ${ }^{\mathrm{I}}$ Maurício Gaudério Dasso ${ }^{\mathrm{III}}$ Sony Dimas Bicudo

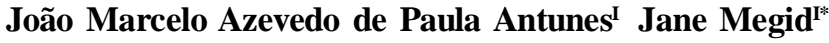

\section{ABSTRACT}

The purpose of this study was to evaluate the agar gel immunodiffusion and the rapid serum agglutination tests associated to clinical signs in rams experimentally infected with Brucella ovis. The serological profile during the 12 months of infection showed a large fluctuation of antibodies that favors the failure in the diagnostic. The evaluation of tests after the experimental infection allowed to suggest that none of the tests were able to detect the infection throughout the period of study. The study reinforces the importance of considering the clinical signs to support the diagnosis of Brucella ovis infection in rams.

Key words: ovine infectious epididimitis, sheep brucellosis, diagnostic.

\section{RESUMO}

O objetivo deste estudo foi avaliar o uso do teste de imunodifusão em gel de ágar e o teste sorológico de aglutinação rápida comparados aos sinais clínicos em carneiros infectados experimentalmente com Brucella ovis para o diagnóstico confirmatório da brucelose ovina. O perfil sorológico durante os 12 meses pós-infecção mostrou flutuação da resposta por anticorpos, que favorece a falha no diagnóstico. A avaliação dos testes indicou que nenhum dos testes foi capaz de detectar a infecção durante todo o período de estudo. $O$ estudo ressalta a importância de considerar os sinais clínicos para apoiar o diagnóstico confirmatório da infecção por Brucella ovis em carneiros.

Palavras-chave: epididimite infecciosa dos ovinos, brucelose ovina, diagnóstico.

\section{INTRODUCTION}

Ovine brucellosis is a disorder caused by Brucella ovis, characterized by infertility in rams, abortion in ewes and increased perinatal mortality in lambs. B. ovis diagnosis is mainly based on a combination of clinical examination, isolation of the microorganism, and detection of antibodies anti-B. ovis in serum samples (BLASCO, 1990; SPICIC et al., 2010). The most common serological methods used in brucellosis diagnosis are agar gel immunodiffusion (AGID), complement fixation test (CFT), and immunoenzymatic tests (ELISA) (WORTHINGTON et al., 1985; BULGIN et al., 1990; HILBINK et al., 1993). All these tests have limitations: AGID shows low sensitivity (ROBLES, 1998); CFT is too complex (KOTT et al., 1998); and ELISA test demonstrates low specificity, and animals that shed the bacteria may be negative (BULGIN et al., 1990). The antigen for serological test recommended by World Organization for Animal Health (OIE) is saline extract antigen (HS), consisting of rough lipopolysacharide and protein components of the outer membrane of Brucella (OIE, 2004). However, cell wall antigen, is not unique to $\boldsymbol{B}$. ovis, because agents like $\boldsymbol{B}$. canis, mucoid species of Pseudomonas aeruginosa and Staphylococcus sp, and Bordetella bronchiseptica has similar antigens

\footnotetext{
IDepartamento de Higiene Veterinária e Saúde Pública, Faculdade de Medicina Veterinária e Zootecnia (FMVZ), Universidade Estadual Paulista (UNESP), Rubião Junior, 18618-970, Botucatu, SP, Brasil. E-mail: jane@fmvz.unesp.br. *Autor para correspondência.

"Empresa Brasileira de Pesquisa Agropecuária, Centro de Pesquisa Agropecuária dos Tabuleiros Costeiros, Aracaju, SE, Brasil.

IIIFundação Estadual de Pesquisa Agropecuária, Instituto de Pesquisas Veterinárias Desidério Finamor, Laboratório de Brucelose, Eldorado do Sul, RS, Brasil.
} 
(CORBELetal., 1985; BAIGUN et al., 2000). AGID based on cytoplasmic protein antigens is highly specific for B. ovis or B. canis infection, since this antigen is common only among the bacteria of the genus Brucella (JOHNSON \& WALKER, 1992). Considering that diagnosis based on indirect detection of antibodies are not completely satisfactory, mainly by the presence of negative animals that eliminate the bacteria, the objective of the present study was to evaluate two diagnostic tests in rams after experimental infection using Agar Gel Immunodiffusion (AGID) [Instituto de Pesquisas Veterinárias Desidério Finamor - IPVDF, Eldorado do Sul/RS, Brazil], and a commercial rapid serum agglutination (SAR) diagnostic test designed for $\boldsymbol{B}$. canis $\left(\mathrm{DTec}-\mathrm{CB}^{\circledR}\right)$. The results of serological tests were associated to clinical signs in order to determine the most effective moment in which each test should be used and the significance of clinical signs as suggestive of Brucella ovis infection in rams.

\section{MATERIALS AND METHODS}

A lyophilized strain of $\boldsymbol{B}$. ovis REO 198 (IPVDF, Eldorado do Sul/RS, Brazil) was used for inoculation. Thirty one Santa Inês breed rams, clinically healthy with 1-2 years of age were used for experimental infection, randomly selected from a known brucellosisfree flock. All animals were tested negative serologically for brucellosis by Agar gel immunodiffusion (AGID), and negative through Polymerase Chain Reaction (PCR) [MANTEROLA et al., 2003] in urine/sperm samples. Rams were tested for the most relevant infectious diseases in sheep (visna-maedi, toxoplasmosis, leptospirosis), and resulted negative. B. ovis suspension containing $2 \times 10^{9} \mathrm{CFU} \mathrm{mL}^{-1}$ was administered by intrapreputial route $(2 \mathrm{~mL})$ and by intraconjunctival route $(50 \mu \mathrm{L})$, simultaneously. After inoculation, blood was collected every week until one year post-challenge. The antigen used in AGID was produced from the reference strain REO 198 (antigen consisted predominantly of surface proteins of the rough strain and significant amounts of LPS) extracted by the method of hot saline, produced by IPVDF. Aiming to rule out infection by Brucella abortus, the samples were tested with rapid agglutination in plate with acidified antigen (AAT) before the AGID test, which was performed according to the manufacturer's recommendation. For the validation of the test, positive and negative control sera from animals known to be infected and free of infection were used, respectively. Readings were taken at 24,48 and 72 hours for lighting system with indirect light and dark background. The result considered was the final reading with 72 hours of incubation in wet chamber. Observing the formation of precipitation line between serum test and the antigen, the samples were classified as positive or negative, according to the interpretation. Those showing identity line with the standard serum were considered positive. The SAR was performed using the commercial kit D-Tec ${ }^{\oplus} \mathrm{CB}$ (Synbiotics Corporation, San Diego, CA 92127 USA). SAR uses an antigen from wall of $\boldsymbol{B}$. ovis inactivated and stained with rose Bengal. It was added $30 \mu \mathrm{L}$ of antigen at $30 \mu \mathrm{L}$ of serum and homogenized for 10 seconds to form a circle about two inches in diameter, after which it was kept at rest for two minutes. At the end of reaction time, the test was considered positive if it had the presence of lumps and the absence of it, the test was considered negative. All rams were submitted to clinical examination weekly, which consisted of measurement of scrotal perimeter and palpation of testicles and epididymis. Width and length of the scrotum were evaluated by means of a caliper. According to RAMOS et al. (1966); RIDLER (2002), clinical alterations for acute (edema of the scrotum/epididymis/testicles) or chronic (hardening of the epididymus, testicular atrophy, epididymis fibrosis and adherences) phases of infection were accomplished. Animals were classified as positive and negative in SAR and AGID, and correlation between results was analyzed. The variables (total seropositives $\mathrm{x}$ total seronegatives) were analyzed by Chi-square (?2) with a significance level of 5\%. The Bioestat 5.0 was used to calculate association $(\mathrm{P}<0.05)$. Initially it was performed the Friedman test for positivity by trimester between the tests. Noting the significance, Wilcoxon paired signed ranks test was chosen using Bonferroni corrections. Means were compared by the MannWhitney test $(\mathrm{P}>5 \%)$. The degree of agreement between SAR and AGID was calculated by means of the maximum and minimum limit of agreement for results obtained in each week, considering a 95\% confidence limit.

\section{RESULTS AND DISCUSSION}

Both tests were statistically significant $(\mathrm{P}<0.05)$ in the first trimester, however, the SAR test was more sensitive in the first 2 weeks. The maximum percentage of positive results was observed in $25(80 \%)$ animals in the $2^{\text {nd }}$ week for SAR and $16(52 \%)$ in the $3^{\text {rd }}$ week for AGID (Figure 1). Positivity in SAR decreased to $80 \%$ to $11 \%$ ( $\left(7^{\text {th }}\right.$ week). Although the percentage of positivity in AGID lowered from $52 \%$ to $3 \%$, this assay detected reactors constantly until the $18^{\text {th }}$ week after inoculation. Antibodies appeared in the $1^{\text {st }}$ week and were detectable in a variable percentage of $30-40 \%$ of 


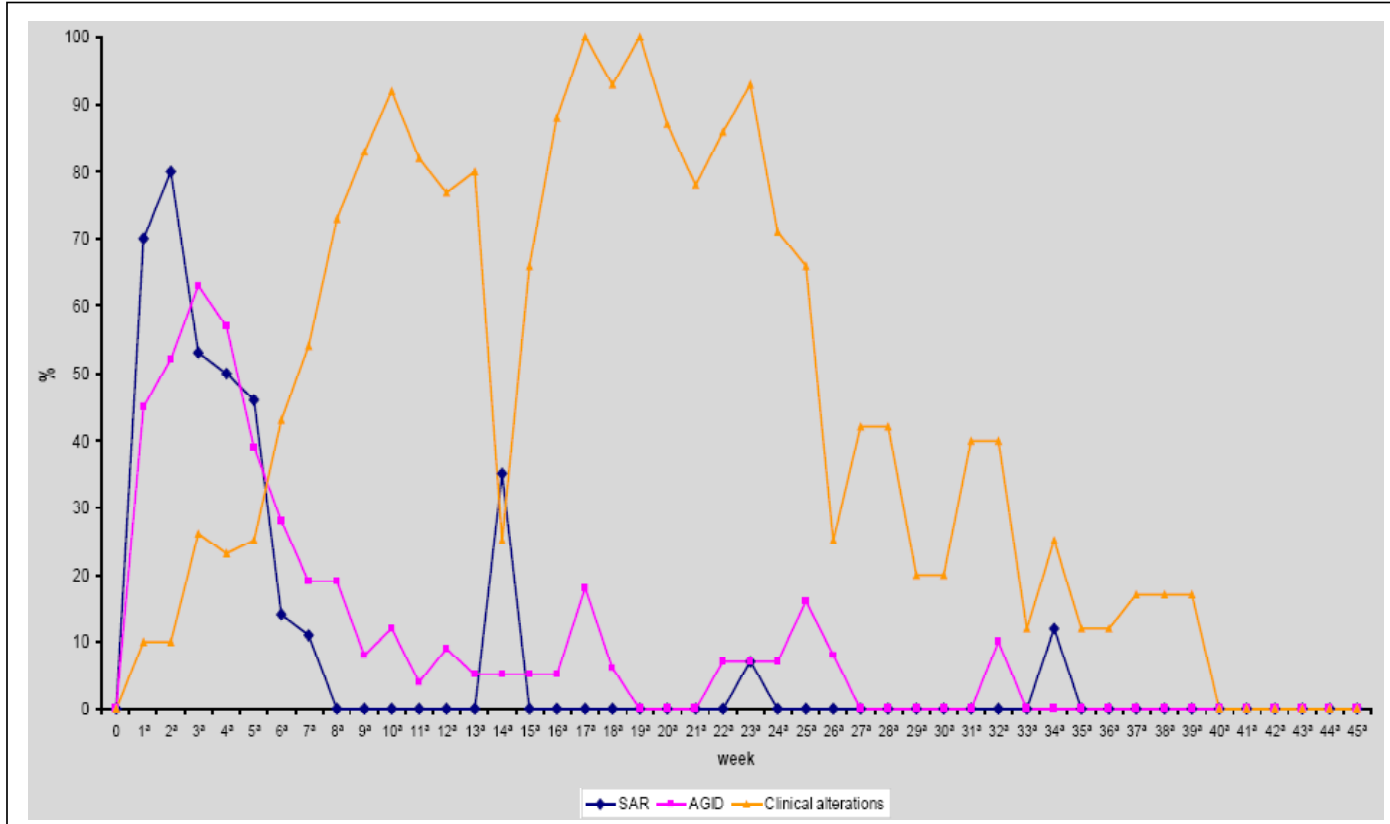

Figure 1 - Percentage of positive animals in the different serological tests correlated with the percentage of clinical alterations of sheep inoculated experimentally with B.ovis in different phases of the disease.

the animals until the $6^{\text {th }}$ week. Clinical signs reached $100 \%$ of the animals, peaking between the $11^{\text {th }}-25^{\text {th }}$ weeks, and remained at $10-20 \%$ in the final phase of the study (Figure 1). Seropositivity was observed both in SAR and AGID since the first week after inoculation, and the fluctuations in the percentage of positive animals were observed in both assays during the experiment. PLANT et al. (1986); NOZAKI et al. (2004) demonstrated similar results using CFT and AGID. AGID using B. ovis cell wall antigen detected 23/31 (74.1\%) of the animals experimentally inoculated, mainly in the initial phase of the disease. This fact is in agreement with previous reports that used cell wall antigen, which is able to detect animals in the acute phase of the disease (NIELSEN \& DUNCAN, 1990; JONHSON \& WALKER, 1992). Antigens used in serological tests are made up of external membrane and rough LPS proteins, where, antigens extracted by hot saline (HS) were not able to detect all infected animals (EISTEN, 1999). AGID detected a lower percentage of positive animals than SAR, however, it was able to detect positive animals during all period of infection (Figure 1). The detection threshold of the technique may justify it, which is greater in precipitation assays than in agglutination tests. Precipitation assays recognize a minimum of $30 \mu \mathrm{g}$ antibodies $\mathrm{mL}^{-1}$, whereas agglutination tests detect $10.05 \mu \mathrm{g} \mathrm{mL}^{-1}$ (MATUKUMA \& RICHTZENHAIN, 1997). AGID demonstrated lower positivity in the acute phase of the disease. According to NIELSEN \& DUNCAN (1990), the antibodies involved in the AGID are mostly of the IgG class. There was no statistical difference between the results obtained in AGID and SAR in relation to the total seropositivity of the animals nor for the quarters analyzed. Statistical analysis determined the limits of agreement between SAR and AGID in the different weeks. Agreement between the tests increased as the disease progressed towards the chronic phase, demonstrating the same antibody detection profile in both tests. Absence of positive results beginning at the $32^{\text {nd }}$ week after inoculation may be justified by the absence of antibodies as a function of the persistence of the bacteria in the reproductive system (NIELSEN \& DUNCAN, 1990). Limits of agreement between SAR and AGID in different weeks, with a 95\% confidence limit, showed a gradual increase in agreement with the evolution of the disease, ending in the $34^{\text {th }}$ week, when no more positive animals were detected. A growing number of animals showing clinical signs were observed beginning in the $1^{\text {st }}$ week after inoculation, peaking between the $11^{\text {th }}(82 \%)$ and $13^{\text {th }}$ week $(80 \%)$, and decreasing soon after the $14^{\text {th }}$ week $(25 \%)$. A new peak was observed from the $17^{\text {th }}$ to the $19^{\text {th }}$ week $(100 \%)$, quickly decreasing after the $23^{\text {rd }}$ week. Until the $60^{\text {th }}$ day after inoculation, the main clinical sign involved only the epididymis: $70 \%$ (22 animals) showed unilateral, and 13\% (4 animals) showed bilateral lesions, mostly related to increased size and consistency, as well as 
hardening of the organ. From day 60 to 6 months after inoculation, testicular lesions were observed in $35 \%$ (9) of the animals and 27\% (7) of the animals showed unilateral epididymis atrophy. Between 6 and 10 months, $28 \%$ (4) of the animals showed sporadic epididymis atrophy. After 10 months of inoculation, no changes were observed in $75 \%$ (6) of the remaining animals. Therefore, the period of acute disease ranged from the $1^{\text {st }}$ to the $4^{\text {th }}$ week after inoculation. After that, the chronic phase ensued (Figure 1). Clinical changes were observed in 25 of the 31 inoculated animals. The main characteristics were increase in size and consistency, and hardening of the organ, with some animals showing testicular lesions and even unilateral epididymis atrophy. Although changes began in the $1^{\text {st }}$ week after inoculation, a greater number of animals showed changes beginning in the $9^{\text {th }}$ week. There were some periods when fewer changes were observed, but the number of animals affected remained high until the $25^{\text {th }}$ week. Similar results were observed in another study that reported clinical lesions in all animals beginning three weeks after inoculation, and lasting for eight weeks (WEBB et al., 1980). According to DELONG et al. (1979), palpable epididymitis may frequently become normal in few weeks. Clinical signs observed in this infection during the acute and chronic phases of the disease were variable, however, similar to the reports of several authors (RAMOS et al., 1966; HUGHES \& CLAXTON, 1968). The analysis of serological results and clinical examination showed that more animals with clinical signs were observed beginning in the $8^{\text {th }}$ week after challenge, when titers began to decrease. Therefore, the association between AGID and clinical examination would produce more reliable results. Although clinical examination alone was enough to characterize affected animals beginning in the $7^{\text {th }}$ week, it may not enable routine diagnosis of the onset of the disease, or exclude other diseases caused by different infectious agents. The serological tests showed good sensitivity in the acute phase of disease, but when the animals had a greater amount of clinical changes over the period, the titers decays or disappear completely as in the serum agglutination test (HUGHES \& CLAXTON, 1968). The use of serological test alone would not diagnose all animals that are potential sources of infection. In this study, the greatest percentages of clinical signs were detected in the acute phase, where, also occurred the negative serological results. WEST et al. (1993), related absence of positive serology and clinical signs in the chronic phase of the disease. According to BLASCO (1990); QUISPE et al. (2002), diagnosis of ovine brucellosis is a necessary association between serological methods and clinical examination.

Despite the low positivity in serodiagnostic tests throughout the study, and the fall of antibody titers after the seventh week, there is an association $(\mathrm{P}<0.001)$ between positivity on either test and clinical signs throughout the weeks (Figure 2). The positivity in either serological test was detected until the $34^{\text {th }}$ week, while the clinical examination was positive until the $41^{\text {st }}$ week. In figure 2 , animals with clinical alterations and negative serology can be visualized, especially after the $34^{\text {th }}$ week. However, changes observed in the acute and chronic phases of the disease varied, and animals could return to the normal condition after some weeks. Other studies reported that infected animals showing palpable epididymitis frequently became normal at clinical examination. Negative serology with excretion of the bacteria reinforces the importance of seronegative animals for the epidemiological chain of the disease (HUGHES \& CLAXTON, 1968; RAMOS et al., 1966; BLASCO, 1990). The low positivity throughout the study by serological tests raises a concern about the animals that remain a source of infection for the herd and maintains the importance of clinical examination.

Few studies reports the serological profile mainly up to 6 months after infection (HUGHES et al., 1968; QUISPE et al., 2002). This study demonstrates the profile until a year after the experimental infection, which shows a sharp decline in antibody titers after the seventh week that favors the possibility of failures in the diagnosis of ovine brucellosis. Another point that should be reviewed is the difficulty of obtaining antigens for diagnosis of ovine brucellosis in Brazil through the AGID. This research suggests the possibility of using a rapid test for canine brucellosis to be used in the diagnosis of ovine brucellosis.

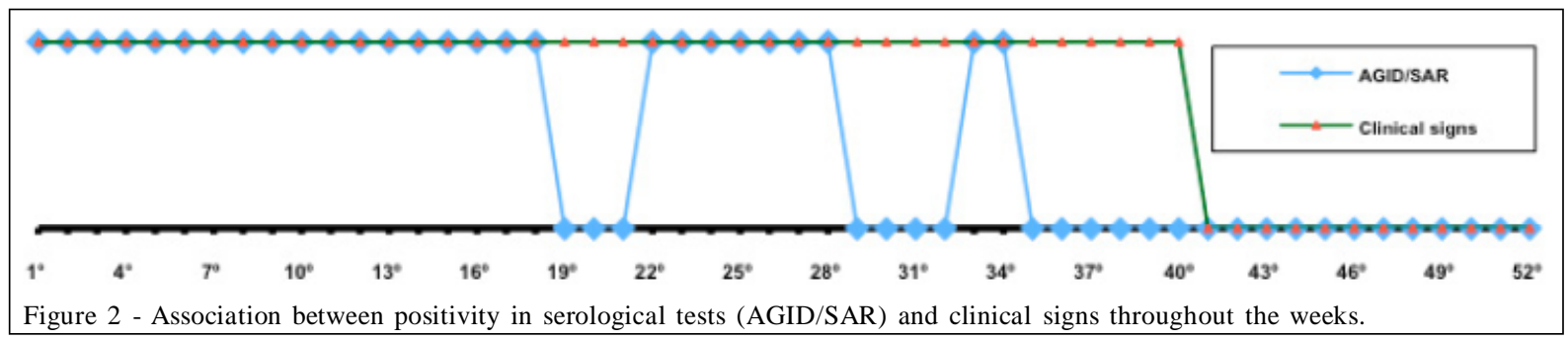

Ciência Rural, v.41, n.8, ago, 2011. 


\section{CONCLUSION}

The diagnosis of infectious epididymitis in rams remains an unsolved problem. The evaluation of tests during the infection allows us to suggest that none of the tests were able to detect the infection throughout the period of study. However, the experimental infection by $\boldsymbol{B}$. ovis is characterized by sharp decline of individual antibodies titers during the development of the disease. This fall of antibodies titers favors the possibility of failures at the diagnosis of ovine brucellosis. The SAR showed greater sensitivity in the first weeks after infection, while AGID detected more positive animals in the chronic phase of the disease. The clinical signs were observed throughout the period of infection. However, clinical signs were observed in seronegative animals, which showed that palpation and clinical examination together are still good methods for monitoring the presence of brucellosis in the flocks. Nonetheless, it is highlighted that the clinical signs should be considered as indicative of clinical suspicion of brucellosis, since there are other causes of ovine epididymitis. Clinical examination in the chronic phase of disease may be an indicator of infected animals. However, it is not possible to determine in which phase of the disease the animal is; the association between AGID and clinical examination should be used in ovine brucellosis diagnosis. Positive animal detected in one or the other method could be an indication of $\boldsymbol{B}$. ovis infection. When serology is negative and clinical results are positive, diagnosis should be confirmed by other methods, such as bacteriological tests or molecular biology techniques, as well as epidemiological evaluation. In summary, the results suggest that both tests, SAR and AGID, were not able to detect brucellosis throughout the period of infection. However, they could be used in different phases of the disease as screening tests to detect infected flocks. Both tests are considered unfavorable for serodiagnosis in ovine brucellosis. This research highlights the importance of clinical signs suggestive of Brucella ovis infection in rams.

\section{ETHICS COMMITTEE AND BIOSAFETY}

Ethics committee protocol n. 69/2008).

\section{ACKNOWLEDGEMENTS} Paulo-FAPESP.

Fundação de Amparo a Pesquisa do Estado de São

\section{REFERENCES}

BAIGUN, R. et al. Aislamiento de Brucella ovis y control de reaccionantes serológicos en epididimitis ovina. Veterinaria
Argentina, v.17, p.102-107, 2000. Available from: <http:// www.veterinariargentina.com/revista/ediciones-anteriores/>. Accessed: Nov. 24, 2010.

BLASCO, M.J.M. Brucelosis ovina: epidemiologia, patogenia y cuadro clínico. In: BLASCO, M.J.M.; MORIVON, U.I. Tratado de patologia y producción ovina. Zaragoza: Luzáns, 1990. p.25-32.

BULGIN, M.S. Brucella ovis excretion in semen of serum negative, clinically normal breeding rams. Journal of the American Veterinary Medical Association, v.196, p.313$315,1990$.

CORBEL, M.J. Recent advances in the study of brucella antigens and their serological cross-reactions. Veterinary Bulletin, v.55, p.927-942, 1985 .

DELONG, W.J. et. al. Bacterial isolates associated with epididymitis in rams from Idaho and Eastern Oregon flocks. American Journal of Veterinary Research, v.40, p.101102, 1979.

QUISPE, R.C. et al. Cinética de la infección por Brucella ovis en carneros durante una época de empadre. Revista de Investigación Veterinaria del Perú, v.13, p.61-66, 2002.

ESTEIN, S.M. Aspectos inmunológicos en el diagnóstico y control de la epidemitis contagiosa del carnero por Brucella ovis. Archivos de Medicina Veterinaria, v.31, n.1, p.5-17, 1999. Available from: <http://www.scielo.cl/scielo.php?script=sci_arttext\&pid=S0301732X1999000100001\&lng=es\&nrm=iso>. Accessed: Oct. 11, 2009. doi: 10.4067/S0301-732X1999000100001.

HILBINK, F. et al. Use of the double gel diffusion test and enzyme-linked immunosorbent assay to distinguish false from true reactors in the complement fixation test for Brucella ovis. New Zealand Veterinary Journal, v.41, p.111-115, 1993. Available from: <http://www.ingentaconnect.com/content/nzva/ nzvj/1993/00000041/00000003/art00002>. Accessed: Jun. 01, 2009.

HUGHES, K.L.; CLAXTON, P.D. Brucella ovis infection: an evaluation of microbiological, serological and clinical methods of diagnosis in the ram. Australian Veterinary Journal, v.44, p.41-47, 1968 . Available from: <http:// onlinelibrary.wiley.com/doi/10.1111/avj.1968.44.issue-2/ issuetoc>. Accessed: Jun. 11, 2009. doi: 10.1111/j.17510813.1968.tb04951.x.

JOHNSON, C.A.; WALKER, R.D. Clinical signs and diagnosis of Brucella canis infection. Compendium on continuing education for the practicing veterinarian, v.14, p.763$772,1992$.

KOTT, R.W. et al. Relationship between Brucella ovis semen culture and various semen and serology parameters. Theriogenology, v.29, p.961-970, 1998. Available from: < h t p : / / w w w. s c i e n c edirect.com / science?_ob=ArticleURL\&_udi=B6TCM-49NY4VBW W \&_us e r $=10 \&$ _ c ove r D a t e $=04 \% 2$ F $30 \% 2$ F

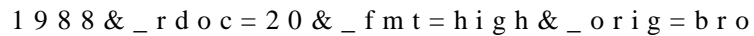
wse\&_origin $=$ browse\&_zone $=$ rslt_list_item $\&$ _srch $=$ docinfor $\% 23$ toc \%235174\%231988\%239997099 $95 \% 23462685 \% 23 \mathrm{FLP} \% 23 \mathrm{display} \% 23 \mathrm{Volu}$ me)\&_cdi=5174\&_sort=d\&_docanchor $=\&$ _ct $=23 \&$ _act $=$ C00005022 
$1 \&$ _version $=1 \&_{\text {_ur }} 1$ Version $=0 \&$ _userid $=10 \& \mathrm{md} 5$ $=4 \mathrm{f} 6 \mathrm{cb} 71973 \mathrm{~b} 23 \mathrm{de} 1 \mathrm{~b} 36 \mathrm{~d} 1 \mathrm{df} 315194 \mathrm{f} 6 \mathrm{a} \&$ searchtype $=\mathrm{a}>$. Accessed: Mar. 10, 2009. doi: 10.1016/0093691X(88)90233-6.

MANTEROLA, L. et al. Evaluation of a PCR test for the diagnosis of Brucella ovis infection in semen samples from rams. Veterinary Microbiology, v.92, p.65-72. Available from: <http:// www.sciencedirect.com/science?_ob=ArticleURL\&_udi=B6TD6472 B JCR-3\&_user $=10 \&$ \& coverDate $=03 \% 2$ F $20 \% 2 \mathrm{~F}$ $2003 \&_{-}$rdoc $=1 \&_{-}$fmt $=$high \&_orig $=$search \&

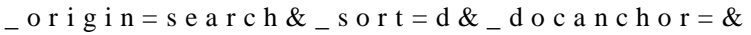
vi e w $=\mathrm{c} \&$ \& c c t $=$ C $000050221 \&$ \& e r sion $=$ $1 \&$ _ u r 1 Version $=0 \&$ _ u se ri d $=10 \&$ m d $5=6$ 08e1376cee258e20cc9e90302f $94 \mathrm{f} 12 \&$ searchtype $=\mathrm{a}>$. Accessed: Jul. 23, 2010. doi: 10.1016/S0378-1135(02)00310-3.

MATUKUMA, C.A.; RICHTZENHAIN, L.J. Testes sorológicos na clínica de pequenos animais. Revista Clínica Veterinária, v.2, n. 8, p.20-23, 1997.

NIELSEN, K.; DUNCAN, J.R. Animal brucellosis. Boca Raton: CRC, 1990. 453p.

PLANT, J.W. et al. Serological, bacteriological and pathological changes in rams following different routes of exposure to Brucella ovis. Australian Veterinary Journal, v.63, p.409412, 1986. Available from: <http://onlinelibrary.wiley.com/ doi/10.1111/avj.1986.63.issue-12/issuetoc>. Accessed: Jul. 12, 2010. doi: $10.1111 /$ j.1751-0813.1986.tb15885.x.

NOZAKI, C.N. et al. Comparação das técnicas de imunodifusão em gel de ágar e ELISA no diagnóstico de brucelose ovina em cabanhas da região centro-oeste do estado de São Paulo. Arquivos do Instituto Biológico, v.71, p.1-5, 2004. Available from: <http://www.biologico.sp.gov.br/docs/arq/V71_1/ nozaki.pdf>. Accessed: Nov. 23, 2010.

RAMOS, A.A. et al. Epididimite ovina: levantamento clínico no Rio Grande do Sul. Pesquisa Agropecuária Brasileira, v.1, p.211-213, 1966.

RIDLER, A.L. An overview of Brucella ovis infection in New Zealand. New Zealand Veterinary Journal, v.50, p.96-98,
2002. Available from: <http://www.ingentaconnect.com/ content/nzva/nzvj/2002/00000050/00000003/art00024>. Accessed: Nov. 24, 2010.

ROBLES, C.A. Evaluación de una técnica de doble difusion em gel de agar para el diagnóstico de la infección por Brucella ovis en carneros. Veterinaria Argentina, v.15, p.119-124, 1998. Available from: <http://www.inta.gov.ar/bariloche/info/ documentos/animal/salud/ct-315.pdf $>$. Accessed: Mar. 10, 2009.

SPICIC, S. et al. Serological, bacteriological and molecular diagnosis of brucellosis in domestic animals in Croatia. Croatian Medical Journal, v.51, p.320-326, 2010. Available from: <http://www.ncbi.nlm.nih.gov/pmc/articles/PMC2931437/pdf/ CroatMedJ_51_0320.pdf>. Accessed: Nov. 24, 2010. doi: $10.3325 / \mathrm{cmj} .2010 .51 .320$.

WEBB, R.F. et al. Evaluation of procedures for the diagnosis of Brucella ovis infection in rams. Australian Veterinary Journal, v.56, p.172-175, 1980. Available from: <http:// onlinelibrary.wiley.com/doi/10.1111/avj.1980.56.issue-4/ issuetoc>. Accessed: Mar. 13, 2010. doi: 10.1111/j.17510813.1980.tb05673.x.

WEST, D.M. et al. Serological and necropsy findings for rams infected with Brucella ovis which were not identified by the complement fixation test. New Zealand Veterinary Journal, v.41, p.82-86, 1993. Available from: <http:// www.ingentaconnect.com/content/nzva/nzvj/1993/00000041/ 00000002/art00005>. Acessed: Nov, 19. 2009.

WORLD ORGANIZATION FOR ANIMAL HEALTH. Manual of standards for diagnostic tests and vaccines for terrestrial animals. Paris: OIE, 2004. Available from: <http:/ /www.oie.int/esp/normes/mmanual/A_00068.htm>. Accessed: Jun. 22, 2010.

WORTHINGTON, R.W. et al. Serology and semen culture for the diagnosis of Brucella ovis infection in chronically infected rams. New Zealand Veterinary Journal, v.33, p.84-86, 1985. Available from: <http://www.ingentaconnect.com/ content/nzva/nzvj/1985/00000033/00000006/art00002>. Accessed: Mar. 12, 2009. 